\title{
The possibility of using natural and synthetic products in control of the willow rust (Melampsora epitea Thüm.) occurring on pussy willow (Salix caprea)
}

\section{Możliwość wykorzystania naturalnych i syntetycznych produktów w ochronie wierzby (Salix caprea) przed rdzą (Melampsora epitea Thüm.)}

\author{
Adam T. Wojdyła*
}

\section{Summary}

The aim of the field experiments was the assessment of influence of double treatment with a foliar fertilizer Actifos, plant growth stimulators Atonik SL, Bioczos liquid, Biosept Active, Huwa-San TR-50, PronTech, vegetal oil Olejan 85 EC and UHT milk on the development of Melampsora epitea symptoms. The obtained results proved that Actifos, Bioczos liquid, Biosept Active and Olejan 85 EC applied curatively for willow control demonstrated 80-97\% efficacy in reducing the quantity of developing uredinia. The effectiveness of Atonik SL, Huwa-San TR-50, PronTech and UHT milk ranged between $40-97 \%$. None of the tested products had a phytotoxic effect on willow.

Key words: Melampsora epitea; rust; willow; control; effectiveness

\section{Streszczenie}

W badaniach polowych oceniano wpływ nawozu dolistnego - Actifos, stymulatorów wzrostu roślin - Atonik SL, Bioczos płynny, Biosept Active, Huwa-San TR-50, PronTech, oleju roślinnego - Olejan 85 EC oraz mleka UHT stosowanych do 2-krotnego opryskiwania wierzby na rozwój objawów chorobowych powodowanych przez Melampsora epitea. Wykazano, że pośród badanych środków Actifos, Bioczos płynny, Biosept Active i Olejan 85 EC użyte interwencyjnie do ochrony wierzby w każdym z przeprowadzonych doświadczeń wykazywały od 80 do $97 \%$ skuteczność w ograniczaniu liczby formujących się uredinii. Z kolei skuteczność środków Atonik SL, Huwa-San TR-50, PronTech oraz mleka UHT wahała się od 40 do $97 \%$. Żaden z badanych środków nie był fitotoksyczny dla wierzby.

Słowa kluczowe: Melampsora epitea; rdza; wierzba; ochrona; skuteczność

\footnotetext{
Instytut Ogrodnictwa

Zakład Ochrony Roślin Warzywnych i Ozdobnych

Konstytucji 3 Maja 1/3, 96-100 Skierniewice
}

*corresponding author: adam.wojdyla@inhort.pl 


\section{Wstęp / Introduction}

Rdza powodowana przez grzyb Melampsora epitea Thüm. jest jedną z najgroźniejszych chorób występujących na wierzbie. Pierwsze objawy w postaci żółtych, okrągłych plam o średnicy 3-4 mm pojawiają się pod koniec czerwca. Po upływie kilku dni na dolnej stronie liści w miejscu plam formowane są wypukłe, pomarańczowe skupienia uredinii. $\mathrm{Na}$ niektórych gatunkach wierzby Salix viminalis L. oraz Salix caprea L. objawy w postaci zarodnikowania rdzy formowane są również na pędach (Pei i Hunter 2000). Jeśli warunki pogodowe są sprzyjające dla rozwoju grzyba (częste opady lub zwilżanie roślin w czasie podlewania, wysoka wilgotność powietrza) następuje gwałtowny rozwój objawów chorobowych połączony z masowym opadaniem liści. Jeśli choroba pojawi się na plantacjach wierzby energetycznej, może obniżyć plon nawet o 40\% (Parker i wsp. 1995). Ograniczenie występowania choroby polega głównie na usuwaniu opadłych liści (uprawy amatorskie), uprawie gatunków i odmian odpornych oraz stosowaniu fungicydów. Dotychczas przeprowadzone badania wykazały wysoka skuteczność fungicydów (Wojdyła 2008; Remlein-Starosta 2014) oraz olejów (Wojdyła i Jankiewicz 2004) w ochronie wierzby przed rdzą.

Celem badań było określenie skuteczności stymulatora wzrostu i rozwoju roślin, środków biotechnicznych, nawozu, oleju i mleka UHT w ograniczaniu rozwoju rdzy wierzby M. epitea.

\section{Materiały i metody / Materials and methods}

W przeprowadzonych badaniach oceniano wpływ różnych środków w ochronie wierzby iwa Pendula (Salix caprea Pendula) przed rdzą (M. epitea Thüm.). W badaniach oceniano skuteczność: nawozu dolistnego Actifos (fosforyn amonowy + mikroelementy $\mathrm{B}, \mathrm{Cu}, \mathrm{Fe}$, Mn, Mo, Zn), stymulatorów wzrostu roślin - Atonik SL $(0,3 \%$ para-nitrofenolanu sodu $+0,2 \%$ orto-nitrofenolanu sodu + 0,1\% 5-nitroguajakolanu sodu), Bioczos płynny (wyciąg $\mathrm{z}$ czosnku w płynie), Biosept Active (33\% ekstraktu z nasion i miąższu grejpfruta), Huwa-San TR-50 (493 g nadtlenku wodoru $+0,32$ g koloidalnego srebra w $1 \mathrm{~kg}$ ), PronTech (40\% chlorki alkilodimetylobenzyloamoniowe należące do czwartorzędowych związków amoniowych oraz $60 \%$ mocznika), oleju - Olejan 85 EC (85\% oleju rzepakowego) oraz mleka UHT o zawartości 3,2\% tłuszczu (Spółdzielnia Mleczarska „MLEKPOL” w Grajewie oddział ZPM w Zambrowie). W 2015 roku zwiększono stężenie mleka do 5 i $10 \%$ oraz włączono do programu Huwa-San TR-50 (tab. 3, 4). We wszystkich doświadczeniach jako fungicyd porównawczy użyto Domark 100 EC (100 g/l tetrakonazolu). Układ doświadczenia, naturalna infekcja roślin oraz obserwacje wykonano zgodnie z wcześniej przyjętą metodyką dotyczącą badań nad oceną skuteczności fungicydów w ochronie wierzby przed rdzą (Wojdyła i Jankiewicz 2004; Wojdyła 2008).

W badaniach polowych przeprowadzonych w latach 2013-2015 oceniano skuteczność wymienionych wcześniej środków w ochronie wierzby przed M. epitea. W latach 2013 i 2014 przeprowadzono po jednej serii doświadczeń, a w roku 2015 przeprowadzono dwie serie na różnych plantacjach przy zróżnicowanym początkowym nasileniu objawów chorobowych. Doświadczenia prowadzono na 3-letniej wierzbie szczepionej na pniu, na której corocznie występuje choroba. W miarę potrzeby rośliny podlewano za pomocą systemu kropelkowego nawadniania. W celu zabezpieczenia plantacji przed chwastami podłoże wyścielono czarną agrowłókniną ściółkującą. Do opryskiwania roślin przystąpiono po wystąpieniu objawów chorobowych, a następnie zabieg powtórzono po 7 dniach.

W obu doświadczeniach rośliny kontrolne opryskiwano wodą. Do opryskiwania zużywano $100 \mathrm{ml}$ cieczy na $1 \mathrm{~m}^{2}$ pokrywając dokładnie górną i dolną stronę blaszek liściowych. Do przygotowania cieczy użytkowej stosowano wodę o temperaturze około $20^{\circ} \mathrm{C} \mathrm{i} \mathrm{pH} 7$, do której wprowadzano badany środek. Jako środek standardowy użyto Domark 100 EC w stężeniu 0,05\%. Przed rozpoczęciem doświadczenia (obserwacja wstępna, wyniki zamieszczono pod tytułem tabel 1-4) oraz po 3 dniach od wykonania drugiego opryskiwania (wyniki w tabelach 1-4) dokonano obserwacji liczby plam na liściu (a po dolnej stronie liści odpowiadającej im liczby skupień uredinii) oraz liczby liści z objawami chorobowymi. Następnie obliczono procent ograniczenia wielkości objawów lub uredinii w stosunku do obiektu kontrolnego (niechronionego) posługując się uproszczonym wzorem Abbotta (Abbott 1925).

Doświadczenia prowadzono w układzie bloków losowych z 4 powtórzeniami po 1 roślinie, na której obserwowano na jednym pędzie 25 liści. Uzyskane dane poddano analizie statystycznej stosując test Duncana.

\section{Wyniki i dyskusja / Results and discussion}

Nawóz dolistny Actifos w zależności od doświadczenia powodował od 7,2- do 36,4-krotne ograniczenie formowania się uredinii w stosunku do obiektu kontrolnego, a jego procentowa skuteczność wahała się od 86,1 do $97,3 \%$ (tab. 1-4). Na wierzbie opryskiwanej badanym nawozem notowano od 18 do 53,1 niższy procent porażonych liści w porównaniu do wierzby kontrolnej. Wysoka skuteczność nawozu w ochronie wierzby przed rdzą (M. epitea) była uwarunkowana obecnością w jego składzie fosforynów. Z dostępnej literatury wynika, że fosforyny indukują odporność w chronionych roślinach oraz bezpośrednio oddziaływują na patogeny (Smillie i wsp. 1989). Podobnie w badaniach innych autorów wykazano wysoką skuteczność fosforynów w zwalczaniu nie tylko patogenów rodzaju Phytophthora (Wieczorek i wsp. 2010), ale również patogenów nalistnych, w tym rdzy (Kowata i wsp. 2012).

Atonik SL - stymulator wzrostu roślin w zależności od doświadczenia powodował od 1,7- do 15,4-krotne ograniczenie formowania się uredinii $\mathrm{w}$ stosunku do obiektu kontrolnego, a jego procentowa skuteczność wahała się od 42 do 93,5\% (tab. 1-4). Na wierzbie opryskiwanej badanym stymulatorem wzrostu notowano podobny (tab. 3) lub o 25 niższy procent porażonych liści w porównaniu do wierzby kontrolnej (tab. 1). Uzyskane wyniki są potwierdzeniem wcześniej prowadzonych badań własnych, w których Atonik SL stosowany do ochrony wierzby 
powodował 7-krotne ograniczenie formujących się uredinii (Wojdyła 2004).

Stymulator wzrostu roślin - Bioczos płynny w zależności od doświadczenia powodował od 4,7- do 17,8-krotne ograniczenie formowania się uredinii w stosunku do obiektu kontrolnego, a jego procentowa skuteczność wahała się od 78,7 do $94,5 \%$ (tab. 1-4). Na wierzbie opryskiwanej badanym środkiem notowano od 22 do 42,8 niższy procent porażonych liści w porównaniu do wierzby kontrolnej. We wcześniej przeprowadzonych badaniach sok z czosnku (Bioczos BR) wykazywał skuteczność dochodzącą do $60 \%$, a stosowany był do ochrony róży przed mączniakiem prawdziwym (Sphaerotheca pannosa var. rosae), czarną plamistością (Diplocarpon rosae) oraz mączniakiem rzekomym (Peronospora sparsa) (Wojdyła 2001).

Biosept Active - stymulator wzrostu roślin w zależności od doświadczenia powodował od 6,3- do 18,2-krotne ograniczenie formowania się uredinii w stosunku do obiektu kontrolnego, a jego procentowa skuteczność wahała się od 84 do $94,5 \%$ (tab. 1-4). Na wierzbie opryskiwanej badanym stymulatorem wzrostu notowano od 20,5 do 31,1 niższy procent porażonych liści $\mathrm{w}$ porównaniu do wierzby kontrolnej. Wysoką skuteczność badanego biopreparatu $\mathrm{w}$ ochronie wierzby przed rdzą potwierdzają badania przeprowadzone na malwie (Saniewska i wsp. 2005). Autorki wykazały, że na malwie opryskiwanej środkiem Biosept 33 SL stwierdzono 5-krotnie

Tabela 1. Skuteczność naturalnych i syntetycznych produktów w ochronie wierzby przed Melampsora epitea

Table 1. Effectiveness of natural and synthetic compounds in control of Melampsora epitea on pussy willow (Salix caprea)

Pierwsze opryskiwanie: 12.06 .2013 - First spraying: 12.06 .2013

Porażenie inicjalne: liczba plam na liść $=9,1$ - Initial infection: number of spots per leaf $=9.1$

\begin{tabular}{l|c|c|c|c}
\hline \multicolumn{1}{c|}{$\begin{array}{c}\text { Ś́dek } \\
\text { Treatment }\end{array}$} & $\begin{array}{c}\text { Stężenie } \\
\text { Concentration } \\
{[\%]}\end{array}$ & $\begin{array}{c}\text { Liczba urednii na liść } \\
\text { Mean number } \\
\text { of uredinia/leaf }\end{array}$ & $\begin{array}{c}\text { Skuteczność } \\
\text { Effectiveness } \\
{[\%]}\end{array}$ & $\begin{array}{c}\text { \% chorych liści } \\
\text { of leaves with disease } \\
\text { symptoms }\end{array}$ \\
\hline Kontrola - Control & - & $69,6 \mathrm{i}$ & $0,00 \mathrm{i}$ & $81,0 \mathrm{f}$ \\
Domark 100 EC & 0,05 & $1,60 \mathrm{ab}$ & $97,7 \mathrm{ab}$ & $31,9 \mathrm{~b}$ \\
Actifos & 0,6 & $1,91 \mathrm{bc}$ & $97,3 \mathrm{bc}$ & $27,9 \mathrm{a}$ \\
Atonik SL & 0,1 & $4,52 \mathrm{~g}$ & $93,5 \mathrm{~g}$ & $56,0 \mathrm{e}$ \\
Bioczos płynny & 2,5 & $6,30 \mathrm{~h}$ & $90,9 \mathrm{~h}$ & $56,0 \mathrm{e}$ \\
Biosept Active & 0,05 & $3,82 \mathrm{e}-\mathrm{g}$ & $94,5 \mathrm{e}-\mathrm{g}$ & $58,9 \mathrm{~d}$ \\
Olejan 85 EC & 1 & $4,10 \mathrm{fg}$ & $94,1 \mathrm{fg}$ & $59,0 \mathrm{e}$ \\
PronTech & 0,05 & $2,84 \mathrm{c}-\mathrm{e}$ & $96,0 \mathrm{c}-\mathrm{e}$ & $52,0 \mathrm{~d}$ \\
PronTech & 0,1 & $1,72 \mathrm{ab}$ & $97,6 \mathrm{ab}$ & $51,0 \mathrm{~d}$ \\
PronTech & 0,15 & $0,70 \mathrm{a}$ & $99,0 \mathrm{a}$ & $26,9 \mathrm{a}$ \\
Mleko UHT 3,2\% & 1 & $2,32 \mathrm{~b}-\mathrm{d}$ & $96,7 \mathrm{~b}-\mathrm{d}$ & $43,9 \mathrm{c}$ \\
Mleko UHT 3,2\% & 2 & $3,21 \mathrm{~d}-\mathrm{f}$ & $95,4 \mathrm{~d}-\mathrm{f}$ & $56,0 \mathrm{e}$ \\
\hline
\end{tabular}

Średnie oznaczone tą samą literą dla poszczególnych kolumn nie różnią się istotnie (5\%) według testu Duncana

Means for each column followed by the same letter do not differ at $5 \%$ level of significance (Duncan's multiple range test)

Tabela 2. Skuteczność naturalnych i syntetycznych produktów w ochronie wierzby przed Melampsora epitea

Table 2. Effectiveness of natural and synthetic compounds in control of Melampsora epitea on pussy willow (Salix caprea)

Pierwsze opryskiwanie: 6.06.2014 - First spraying: 6.06.2014

Porażenie inicjalne: liczba plam na liść $=11,4$ - Initial infection: number of spots per leaf $=11.4$

\begin{tabular}{l|c|c|c|c}
\hline \multicolumn{1}{c|}{$\begin{array}{c}\text { Środek } \\
\text { Treatment }\end{array}$} & $\begin{array}{c}\text { Stężenie } \\
\text { Concentration } \\
{[\%]}\end{array}$ & $\begin{array}{c}\text { Liczba urednii na liść } \\
\text { Mean number } \\
\text { of uredinia/leaf }\end{array}$ & $\begin{array}{c}\text { Skuteczność } \\
\text { Effectiveness } \\
{[\%]}\end{array}$ & $\begin{array}{c}\text { \% chorych liści } \\
\% \text { of leaves with disease } \\
\text { symptoms }\end{array}$ \\
\hline Kontrola-Control & - & $61,45 \mathrm{~h}$ & $0,00 \mathrm{~h}$ & $95,0 \mathrm{c}$ \\
Domark 100 EC & 0,05 & $5,01 \mathrm{a}$ & $91,85 \mathrm{a}$ & $61,5 \mathrm{a}$ \\
Actifos & 0,6 & $8,52 \mathrm{~b}$ & $86,14 \mathrm{~b}$ & $77,0 \mathrm{~b}$ \\
Atonik SL & 0,1 & $13,85 \mathrm{c}$ & $76,96 \mathrm{c}$ & $83,0 \mathrm{bc}$ \\
Bioczos płynny & 2,5 & $5,38 \mathrm{a}$ & $91,24 \mathrm{a}$ & $52,2 \mathrm{a}$ \\
Biosept Active & 0,05 & $4,08 \mathrm{a}$ & $93,36 \mathrm{a}$ & $74,5 \mathrm{~b}$ \\
Olejan 85 EC & 1 & $8,59 \mathrm{~b}$ & $86,02 \mathrm{~b}$ & $83,9 \mathrm{bc}$ \\
PronTech & 0,05 & $32,10 \mathrm{f}$ & $47,76 \mathrm{f}$ & $82,9 \mathrm{bc}$ \\
PronTech & 0,1 & $20,15 \mathrm{e}$ & $67,21 \mathrm{e}$ & $88,0 \mathrm{bc}$ \\
PronTech & 0,15 & $13,79 \mathrm{c}$ & $77,56 \mathrm{c}$ & $82,9 \mathrm{bc}$ \\
Mleko UHT 3,2\% & 1 & $36,93 \mathrm{~g}$ & $39,90 \mathrm{~g}$ & $96,0 \mathrm{c}$ \\
Mleko UHT 3,2\% & 2 & $16,85 \mathrm{~d}$ & $72,58 \mathrm{~d}$ & $84,9 \mathrm{bc}$ \\
\hline
\end{tabular}

Średnie oznaczone tą samą literą dla poszczególnych kolumn nie różnią się istotnie (5\%) według testu Duncana

Means for each column followed by the same letter do not differ at $5 \%$ level of significance (Duncan's multiple range test) 
Tabela 3. Skuteczność naturalnych i syntetycznych produktów w ochronie wierzby Melampsora epitea

Table 3. Effectiveness of natural and synthetic compounds in control of Melampsora epitea on pussy willow (Salix caprea)

Pierwsze opryskiwanie: 3.07 .2015 - First spraying: 3.07.2015

Porażenie inicjalne: liczba plam na liść $=15,4-$ Initial infection: number of spots per leaf $=15.4$

\begin{tabular}{l|c|c|c|c}
\hline \multicolumn{1}{c|}{$\begin{array}{c}\text { Środek } \\
\text { Treatment }\end{array}$} & $\begin{array}{c}\text { Stężenie } \\
\text { Concentration } \\
{[\%]}\end{array}$ & $\begin{array}{c}\text { Liczba urednii na liść } \\
\text { Mean number } \\
\text { of uredinia/leaf }\end{array}$ & $\begin{array}{c}\text { Skuteczność } \\
\text { Effectiveness } \\
{[\%]}\end{array}$ & $\begin{array}{c}\text { \% chorych liści } \\
\text { of leaves with disease } \\
\text { symptoms }\end{array}$ \\
\hline Kontrola - Control & - & $81,86 \mathrm{i}$ & $0,00 \mathrm{c}$ & $82,9 \mathrm{~g}$ \\
Domark 100 EC & 0,05 & $3,67 \mathrm{a}$ & $95,52 \mathrm{a}$ & $34,0 \mathrm{a}$ \\
Actifos & 0,6 & $8,75 \mathrm{e}$ & $89,31 \mathrm{a}$ & $38,2 \mathrm{~b}$ \\
Atonik SL & 0,1 & $6,12 \mathrm{~b}-\mathrm{d}$ & $92,52 \mathrm{a}$ & $84,0 \mathrm{~g}$ \\
Bioczos płynny & 2,5 & $4,59 \mathrm{ab}$ & $94,40 \mathrm{a}$ & $53,4 \mathrm{c}$ \\
Biosept Active & 0,05 & $10,54 \mathrm{f}$ & $87,12 \mathrm{ab}$ & $60,0 \mathrm{~d}$ \\
Huwa-San TR-50 & 0,05 & $11,55 \mathrm{f}$ & $85,89 \mathrm{ab}$ & $60,2 \mathrm{~d}$ \\
Olejan 85 EC & 1 & $6,75 \mathrm{~cd}$ & $91,75 \mathrm{a}$ & $67,9 \mathrm{ef}$ \\
PronTech & 0,05 & $8,64 \mathrm{e}$ & $89,45 \mathrm{a}$ & $60,0 \mathrm{~d}$ \\
PronTech & 0,1 & $7,65 \mathrm{de}$ & $90,65 \mathrm{a}$ & $62,5 \mathrm{de}$ \\
PronTech & 0,15 & $5,37 \mathrm{a}-\mathrm{c}$ & $93,44 \mathrm{a}$ & $49,9 \mathrm{c}$ \\
Mleko UHT 3,2\% & 5 & $28,85 \mathrm{~h}$ & $64,75 \mathrm{a}$ & $72,4 \mathrm{f}$ \\
Mleko UHT 3,2\% & 10 & $13,61 \mathrm{~g}$ & $83,37 \mathrm{ab}$ & $72,0 \mathrm{f}$ \\
\hline
\end{tabular}

Średnie oznaczone tą samą literą dla poszczególnych kolumn nie różnią się istotnie (5\%) według testu Duncana

Means for each column followed by the same letter do not differ at $5 \%$ level of significance (Duncan's multiple range test)

Tabela 4. Skuteczność naturalnych i syntetycznych produktów w ochronie wierzby przed Melampsora epitea

Table 4. Effectiveness of natural and synthetic compounds in control of Melampsora epitea on pussy willow (Salix caprea)

Pierwsze opryskiwanie: 10.07.2015 - First spraying: 10.07.2015

Porażenie inicjalne: liczba plam na liść $=6,8$ - Initial infection: number of spots per leaf $=6.8$

\begin{tabular}{l|c|c|c|c}
\hline \multicolumn{1}{c|}{$\begin{array}{c}\text { Środek } \\
\text { Treatment }\end{array}$} & $\begin{array}{c}\text { Stężenie } \\
\text { Concentration } \\
{[\%]}\end{array}$ & $\begin{array}{c}\text { Liczba urednii na liść } \\
\text { Mean number } \\
\text { of uredinia/leaf }\end{array}$ & $\begin{array}{c}\text { Skuteczność } \\
\text { Effectiveness } \\
{[\%]}\end{array}$ & $\begin{array}{c}\text { \% chorych liści } \\
\text { of leaves with disease } \\
\text { symptoms }\end{array}$ \\
\hline Kontrola - Control & - & $42,31 \mathrm{j}$ & $0,00 \mathrm{~d}$ & $85,0 \mathrm{f}$ \\
Domark 100 EC & 0,05 & $2,58 \mathrm{a}$ & $93,90 \mathrm{a}$ & $37,0 \mathrm{a}$ \\
Actifos & 0,6 & $3,57 \mathrm{ab}$ & $91,56 \mathrm{a}$ & $37,9 \mathrm{ab}$ \\
Atonik SL & 0,1 & $24,55 \mathrm{i}$ & $41,97 \mathrm{c}$ & $63,0 \mathrm{~d}$ \\
Bioczos płynny & 2,5 & $9,01 \mathrm{e}$ & $78,70 \mathrm{a}-\mathrm{c}$ & $63,0 \mathrm{~d}$ \\
Biosept Active & 0,05 & $6,77 \mathrm{~d}$ & $84,00 \mathrm{ab}$ & $53,0 \mathrm{c}$ \\
Huwa-San TR-50 & 0,05 & $20,68 \mathrm{~h}$ & $51,12 \mathrm{bc}$ & $65,2 \mathrm{de}$ \\
Olejan 85 EC & 1 & $4,97 \mathrm{bc}$ & $88,25 \mathrm{a}$ & $42,0 \mathrm{~b}$ \\
PronTech & 0,05 & $14,23 \mathrm{~g}$ & $66,36 \mathrm{a}-\mathrm{c}$ & $70,5 \mathrm{e}$ \\
PronTech & 0,1 & $12,09 \mathrm{f}$ & $71,42 \mathrm{a}-\mathrm{c}$ & $55,9 \mathrm{c}$ \\
PronTech & 0,15 & $5,57 \mathrm{~cd}$ & $86,83 \mathrm{ab}$ & $36,9 \mathrm{a}$ \\
Mleko UHT 3,2\% & 5 & $24,39 \mathrm{i}$ & $42,35 \mathrm{c}$ & $78,9 \mathrm{f}$ \\
Mleko UHT 3,2\% & 10 & $14,86 \mathrm{~g}$ & $64,87 \mathrm{a}-\mathrm{c}$ & $71,0 \mathrm{e}$ \\
\hline
\end{tabular}

Średnie oznaczone tą samą literą dla poszczególnych kolumn nie różnią się istotnie (5\%) według testu Duncana

Means for each column followed by the same letter do not differ at $5 \%$ level of significance (Duncan's multiple range test)

mniej porażonych liści oraz mniejszą liczbę skupień teliospor na blaszkach i ogonkach liściowych w porównaniu do roślin kontrolnych.

Stymulator wzrostu roślin - Huwa-San TR-50 w zależności od doświadczenia powodował od 2,1- do 7,1-krotne ograniczenie formowania się uredinii w stosunku do obiektu kontrolnego, a jego procentowa skuteczność wahała się od 51,1 do $85,9 \%$ (tab. 3, 4). Na wierzbie opryskiwanej badanym stymulatorem wzrostu notowano od 19,8 do 22,7 niższy procent porażonych liści w porównaniu do wierzby kontrolnej. Wysoką skuteczność badanego środka $\mathrm{w}$ ochronie wierzby przed rdzą potwier- dzają wcześniejsze badania własne przeprowadzone na pelargonii (Wojdyła 2012). Huwa-San TR-50 zastosowany do ochrony pelargonii przed rdzą (Puccinia pelargoniizonalis) powodował 3,8-5-krotne ograniczenie liczby uredinii w porównaniu do kontroli.

Stymulator wzrostu roślin - PronTech w zależności od doświadczenia i użytego stężenia powodował od 1,7- do 99,4-krotne ograniczenie formowania się uredinii w stosunku do obiektu kontrolnego, a jego procentowa skuteczność wahała się od 47,8 do $99 \%$ (tab. 1-4). Na wierzbie opryskiwanej badanym środkiem notowano od 7 do 54,1 niższy procent porażonych liści w porównaniu 
do wierzby kontrolnej. Wzrost stężenia środka PronTech użytego do opryskiwania wiązał się z istotnym wzrostem jego skuteczności. W dostępnej literaturze jedynie według danych firmy produkującej środek można stwierdzić, że przy stężeniu 200 ppm substancji czynnej w wodzie niszczy on prawie w $100 \%$ wirusy, bakterie oraz grzyby.

Olej roślinny - Olejan 85 EC w zależności od doświadczenia powodował od 7,2- do 17-krotne ograniczenie formowania się uredinii w stosunku do obiektu kontrolnego, a jego procentowa skuteczność wahała się od 86 do $94,1 \%$ (tab. 1-4). Na wierzbie opryskiwanej badanym olejem notowano od 11,1 do 43 niższy procent porażonych liści. Podobnie we wcześniejszych badaniach własnych Olejan 85 EC w stężeniu $1,0 \%$ stosowany do ochrony wierzby przed rdzą (M. epitea) powodował przynajmniej 2,3-krotne ograniczenie formujących się uredinii w porównaniu do kontroli (Wojdyła 2010). Natomiast stosowany w stężeniu od 0,5 do $2 \%$, w zależności od stężenia ograniczał od 2- do 10-krotnie liczbę formujących się uredinii (Wojdyła i Jankiewicz 2004).

Mleko UHT 3,2\% w zależności od doświadczenia oraz użytego stężenia powodowało od 1,7- do 21,7-krotne ograniczenie formowania się uredinii $\mathrm{w}$ stosunku do obiektu kontrolnego, a jego procentowa skuteczność wahała się od 39,9 do $96,7 \%$ (tab. 1-4). Na wierzbie opryskiwanej mlekiem notowano nawet w zależności od doświadczenia do 37,1 niższy procent porażonych liści w po- równaniu do wierzby kontrolnej. Dane literaturowe wskazują, że mleko z powodzeniem może być stosowane do ochrony niektórych gatunków warzyw i roślin sadowniczych przed sprawcami mączniaka prawdziwego (Nam i wsp. 2005; Ferrandino i Smith 2007).

Fungicyd Domark 100 EC wykazywał istotnie wyższą lub podobną skuteczność w ochronie wierzby przed rdzą w porównaniu do badanych produktów.

\section{Wnioski / Conclusions}

1. Nawóz dolistny - Actifos, stymulatory wzrostu roślin Bioczos płynny, Biosept Active i olej roślinny - Olejan 85 EC użyte interwencyjnie do ochrony wierzby w każdym z przeprowadzonych doświadczeń wykazywały od 80 do $97 \%$ skuteczność w ograniczaniu liczby formujących się uredinii.

2. Skuteczność stymulatorów wzrostu roślin: Atonik SL, Huwa-San TR-50, PronTech oraz mleka UHT również przekraczała $80 \%$, jednak w niektórych doświadczeniach (sezon 2014 i 2015) obniżała się do poziomu $40-51 \%$.

3. Żaden z badanych produktów nie był fitotoksyczny w stosunku do wierzby, na której prowadzono badania.

\section{Literatura / References}

Abbott W.S. 1925. A method for computing the effectiveness of an insecticide. Journal of Economic Entomology 18: $265-267$.

Ferrandino F.F., Smith V.L. 2007. The effect of milk-based foliar sprays on yield components of field pumpkins with powdery mildew. Crop Protection 26: 657-663.

Kowata L.S., Alves G., Moreira L.M., May-De Mio L.L. 2012. Potassium, calcium and copper phosphite to control peach rust and brown rot. IDESIA (Chile) 30, (3), Septiembre-Diciembre: 93-96.

Nam M.H., Lee W.K., Kim N.G., Kim H.G. 2005. Control efficacy of milk concentration against powdery mildew of strawberry. Plant Pathology Journal 21 (3): 270-274.

Parker S.R., Pei M.H., Royle D.J., Hunter T., Whelan M.J. 1995. Epidemiology, population dynamics and management of rust diseases in willow energy plantations. Final Report of Project ETSU B/W6/00214/REP. Energy Technology Support Group, Department of Trade and Industry, UK. www.researchinformation.co.uk/pest/2000/B006242L.PDF [Accessed: 10.02.2016].

Pei M., Hunter T. 2000. Integrated control of willow rust in renewable energy plantations in the UK. Pesticide Outlook August: $145-148$.

Remlein-Starosta D. 2014. Ochrona wierzby krzewiastej i ślazowca pensylwańskiego przed chorobami oraz jej wpływ na bioróżnorodność grzybów fyllosfery. Rozprawy Naukowe Instytut Ochrony Roślin - Państwowy Instytut Badawczy, Zeszyt 30, 109 ss.

Saniewska A., Jarecka A., Marasek A. 2005. Biopreparat Biosept 33 SL w ograniczaniu rozwoju rdzy malwy ogrodowej. [Influence of biopreparation Biosept $33 \mathrm{SL}$ on the development of Alcea rosea L. rust]. Zeszyty Problemowe Postępów Nauk Rolniczych 504: 689-696.

Smillie R., Grant B.R., Guest D. 1989. The mode of action of phosphite: Evidence for both direct and indirect modes of action on three Phytophthora spp. in plants. Phytopathology 79: 921-926.

Wieczorek W., Orlikowski L.B., Świętosławski J., Ptaszek M. 2010. Nowy fosforyn do ochrony roślin ozdobnych przed gatunkami Phytophthora. [New phosphite for protection of ornamental plants against Phytophthora spp.]. Zeszyty Problemowe Postępów Nauk Rolniczych 554 (1): 277-283.

Wojdyła A.T. 2001. Garlic juice in the control of some rose diseases. Bulletin of the Polish Academy of Science - Biological Sciences 49 (3): 253-263.

Wojdyła A.T. 2004. Effectiveness of Atonik SL in the control of powdery mildew, black spot, and rust. Folia Horticulturae, Annalis 16/1: $175-181$

Wojdyła A.T. 2008. Wpływ związków strobilurynowych na rozwój Melampsora epitea. [Influence of strobilurin compounds on the development of Melampsora epitea]. Progress in Plant Protection/Postępy w Ochronie Roślin 48 (2): 548-551.

Wojdyła A.T. 2010. Potential use of Olejan 85 EC for protecting some species of ornamental plants against diseases. Journal of Plant Protection Research 50 (2): 164-171.

Wojdyła A.T. 2012. Możliwość wykorzystania środka Huwa-San TR-50 w ochronie roślin ozdobnych przed patogenami nalistnymi. [The possibility of using the preparation Huwa-San TR-50 in the protection of ornamental plants against leaf pathogens]. Progress in Plant Protection/Postępy w Ochronie Roślin 52 (1): 106-111.

Wojdyła A.T., Jankiewicz D. 2004. Oils activity against Melampsora epitea on willow. Communications in Agricultural and Applied Biological Sciences Ghent University 69: 697-703. 